\title{
ABOVE PROPORTIONS
}

\section{Reinterpretation of proportion - in between a conceptual and perceptive view of architecture (a communicative dimension of the city)}

\section{A B S T R A C T}

This paper views proportion as a tool used by planners and architects to achieve a certain quality of space. Considering that proportion is used to observe the correlations between the whole and its parts, the paper examines the aspects of space from the spatial plan of a city to the architectural details. Also, despite the fact that proportion is the correlation of the dimensions of physical elements in space, the paper also perceives proportion through the correlation of the material and immaterial aspects of space. In this way, the focus is shifted onto the level of communication between the architectural - urban space and its users, that is, to orchestration through the perception and experience of space, rather than the outdated, proportional analysis of architectural form. 


\section{INTRODUCTION}

Space is infinite, an unlimited, indefinite volume 1 in which objects, people and events have relevant positions, trends and correlations. Infinity and perpetuity, that is, any type of a lack of determinedness is not empirically possible, so they cannot be perceived directly and sensually. In order to perceive space and time, man limits them, establishing relationships that are anthropometric, by using various means, such as the horizon, abstract and mathematical models or materialized elements, such as walls, rivers, roofs, skin and the like. In this way, by perceiving borders, anthropometric dimensions and relationships, man indirectly perceives space and time, as it is not empirically possible to do otherwise.

In considering anthropometry by way of architecture, the study focuses on design according to human dimensions, that is, space on a human scale. The idea of design according to human proportions and dimensions dates back to Ancient Greece. This sort of design implies buildings which are designed according to canonized mathematical models in relation to the human scale, aesthetically well proportioned and conveying a certain sense of rightness and harmony. ${ }^{2}$

In architecture, the whole is not just a building but the set and surroundings of the site. The factors that make a building and its site "well shaped" include the orientation of the site and the buildings on it to the features of the grounds on which it is situated. Light, shade, wind, elevation, choice of materials - all should relate to a standard and say what is it that makes it what it is, and what is it that makes it not something else. Vitruvius thought of proportion in terms of unit fractions such as those used in the Greek Orders of Architecture. ${ }^{3}$

Proportion is a correspondence among the measures of the members of an entire work, and of the whole to a certain part selected as standard. From this result the principles of symmetry. Without symmetry and proportion there can be no principles in the design of any temple; that is, if there is no precise relation between its members as in the case of those of a well shaped man. ${ }^{4}$

\section{IN BETWEEN - A CONCEPTUAL AND PERCEPTIVE VIEW OF ARCHITECTURE}

When creating spatial plans and establishing spatial systems, special attention is given to the determining of the dimensions and alignment of all the elements, the correlations between the elements, as well as the relation of the parts and the whole. ${ }^{5}$ Since the dimensions of the parts and the whole of the system are 
interrelated, the ratio of the mentioned dimensions is called a proportion. In an effort to establish a synchronized relationship of the parts and the whole, various mathematical models were created, that is, arithmetic and geometric proportion systems, based on the repetition of the created relationship and the increase in the size of the same. There are two types of dimensions in architecture, whereupon the contemporaneous along with technical properties also have aesthetic characteristics. The aesthetic properties are based on the belief that numerical or mathematical values define and establish a visual harmony of space. In order to achieve a certain aesthetic space, there were various attempts throughout history to establish the appropriate mathematically justified proportions whose use would lead to certain aesthetic aspirations. It is necessary to emphasize that in addition to the aforementioned mathematical principles, in architecture there are also metaphysical elements of harmony which are related to the experience and perception of space, as well as emphasizing specific details or segments in relation to the overall system. During the creative process of creating an architectural work of art, it is necessary to connect and establish equal relations between all elements of a proportional harmony in order to establish a certain quality of a future spatial system.

The creative impulse of architects from the Renaissance is considered via the correlation of architecture and natural structures. Arithmetic and geometric systems were first substantiated by the incidence of the natural form in order to confirm their authenticity. Namely, in the development of an artistic interpretation of man's creativity, the idea of harmonious proportions was shaped via the correlation of architectural structures and the structures of the human body. In the $20^{\text {th }}$ century, Le Corbusier [Charles - Eduoard Jeanneret - Gris] developed a scale of proportion called The Modulor [Le Modulor] with the idea that the implementing of this proportional scale would attain the required harmony and functionality within a work of architecture. The Modulor was based and established on the golden ratio and the Fibonacci numbers, as well as da Vinci's [Leonardo da Vinci] Vitruvian Man. ${ }^{6}$ The main idea is based on establishing a universal scale that in addition to the application in architectural creativity should also be used in the field of industrial design. Le Corbusier is this way aspired towards establishing a system of measurement in order to achieve harmony and suit the human scale by an architectural, that is, a functional and spatial composition. It is also necessary to view the context in which The Modulor was formed, and which implied intensified restoring and rebuilding after World War 2. Mass production incited a typological, modular optimization of architectonic production, which was one of the aims for forming The Modulor in the mid-20th century. ${ }^{7}$ 


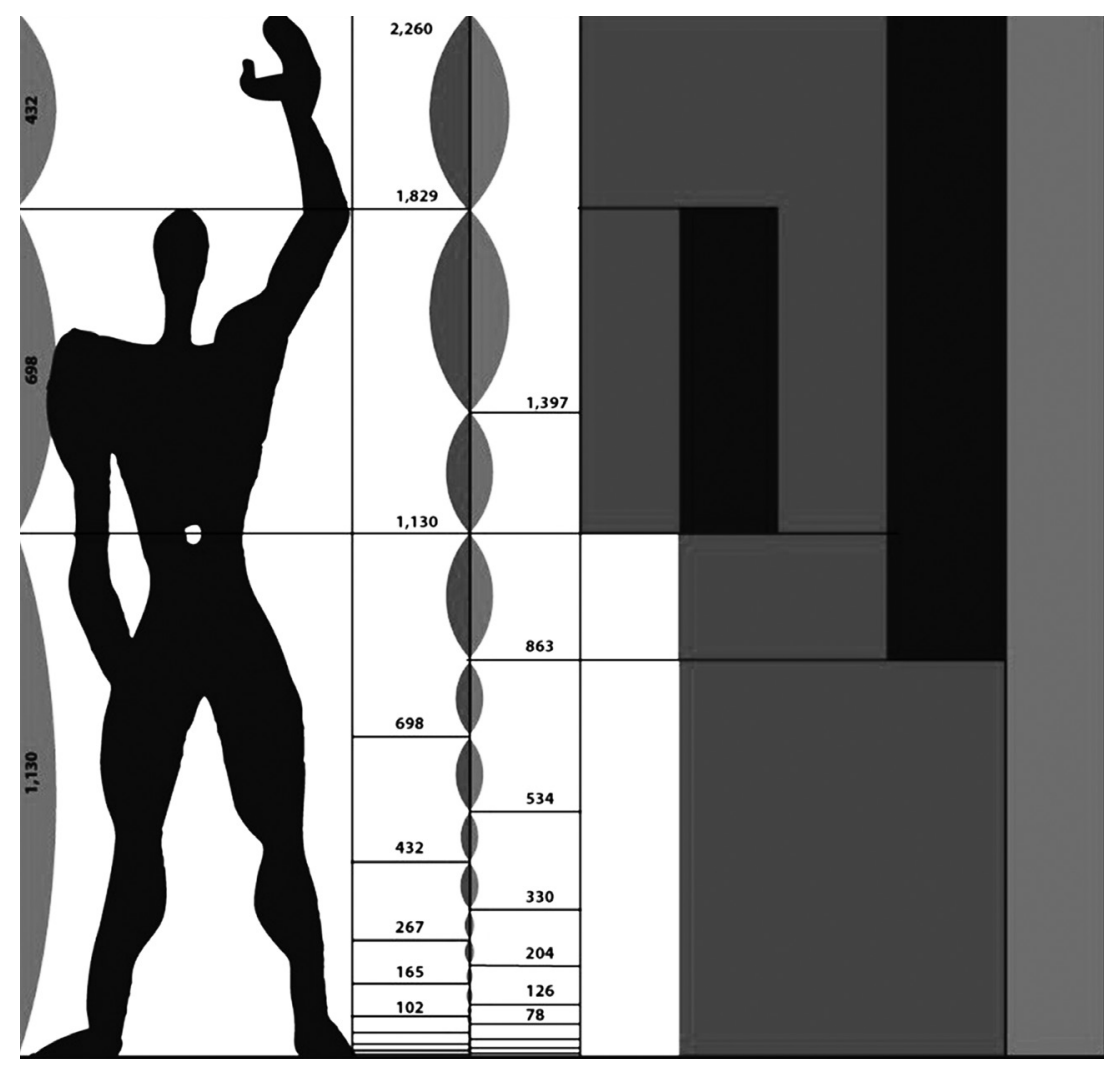

Figure 1. Le Corbusier-Le Modulor. 
The establishment of such a scale has shifted the focus from the formal and stylistic characteristics of a work of architecture to its functional characteristics. The development of the functionalist method, that is, the correlation of architectural structures and the structures of the human body is increasingly used in order to standardize the optimal rate of architectural space, that is, the space of everyday life.

[...] take a man-with-arm-upraised, $2.20 \mathrm{~m}$. in height; put him inside two squares, 1.10 by 1.10 meters each, superimposed on each other; put a third square astride these first two squares. This third square should give you a solution. The place of the right angle should help you decide where to put this third square. With this grid for use on the building site, designed to fit the man placed within it, I am sure you will obtain a series of measures reconciling human stature [man-with-arm upraised] and mathematics $[\ldots]^{8}$

The later development of ergonomics has shown that the dynamics of the use of space and the change in the position of man in space were ignored, and later ergonomic research sought to find the most appropriate correlation - which would include different size variations induced by movements of the human body, depending on the use of space. ${ }^{9}$ The study of motion, that is, the static and dynamic use of space in the everyday, launched the theme related to the perceptual interpretation of dimensional correlations established in architectural work.

A proportional diagram is a means, not a prescription. Its choice and ways of expressing are an integral part of architectural creativity. ${ }^{10}$

It should also be noted that the use of The Modulor assumes the exclusion of certain proportional errors and a tool for forming the standard elements of architectural structures and establishing their correlations which would represent a condition for a particular aesthetic, but excludes the artistic aspect which was initially undefined and unquestionably subjective. The artistic element is part of an intuitive creative impulse and manifests itself as a quality that cannot be defined by scale or principle, but rather, by the individual sensibility of the author. Furthermore, the idea of space and its design presents an original interpretation of creative thinking, and thus architectural work embodies the spatial thinking of architecture interpreted through a coupling of techniques and tools used by the architect, his philosophy of architecture, understanding of space and time, and the internal reflex of a creator. ${ }^{12}$ 


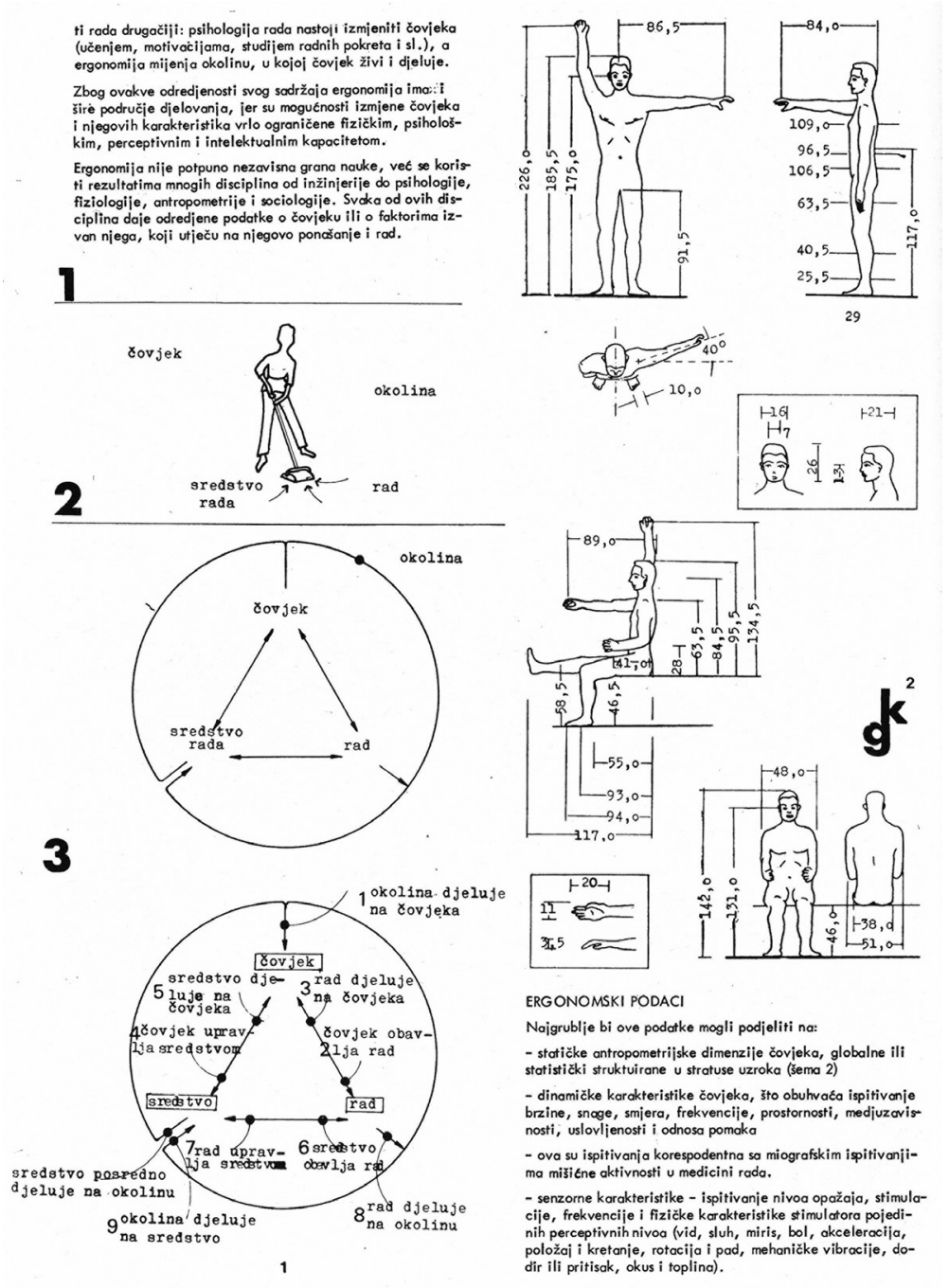

154

Figure 2. The explanation of ergonomics from Notice No. 14, p. 154." 
The previously mentioned research of movement, that is, the static and dynamic use of everyday space, raises the issue of existential, vital values of architectural space. There are in architecture proportions that regulate the correlations of materials, brightness and colour; and further, the correlated textures, shades, hardness and weight.

When speaking of the specified method of establishing proportions, the interpretation of the same is twofold: it can be interpreted from the perspective of the designer and author and from the perspective of the viewer and the user; also, we can speak about their correlation and the manifestations of their interlocking and advancement via the architectural work of art. Of course, it is necessary for the creative process not to be interpreted as an assumed and predetermined matrix, but as a specially established theoretical and conceptual framework that permits flexibility for individual approaches. ${ }^{13}$

Thereby, when it comes to interpretation from the perspective of the author of the project, we are calling for the creator's conceptual thinking in this paper. When mentioning observers of space, it opens the issue of a perceptive opinion, that is, the topics relating to multi-layered sensory perceptions which the viewer enjoys by attaining communication with artwork, whereupon a corresponding space for the development of critical thinking appears. If we are talking about the user of the space, the architectural space, the vitality of the area and its existential value is considered through proportional harmony and dimensional correlations. Due to a long tradition of attempts to discover the harmonization of the dimensions of elements and parts of an architectural work of art, it was found that dimensions, and thus the harmony depend on the angle of observation, the position of the viewer with respect to details, the distance from the facility, as well as the light in the environment. Based on the afore mentioned, it was concluded that perception depends not only on the position and conditions, but also on the physical and mental condition of the user/viewer, which is subject to change. Also, it is necessary to mention the fact that a system that could assume all possible scenarios cannot be established, as well as that the proportions are in conjunction with individual sensibility.

To me, there is something revealing about work of Joseph Beuys and some of the artists of the Arte Povera group. What impresses me is the precise and sensuous way they use materials. It seems anchored in an ancient, elemental knowledge about man's use of materials, and at the same time to expose the very essence of these materials which is beyond all culturally conveyed meaning. ${ }^{14}$ 
Peter Zumthor is of the opinion that materials are the ones which can enable a poetic quality of the architectural work of art in the given context. This implies that materials are not significant for an idea, but they contribute to the atmosphere of the space, which means that they take part in the impression of space. However, this is possible only if the architect as an author enables a significant position, correlation and arrangement of the same - for, as it is said: [...] materials in themselves are not poetic. ${ }^{15}$

So, the essence of proportion can be both in an architectural unconventional scenario. However, the sense of architecture that Zumthor was trying to implement by using the precision of certain materials and their mutual correlations exceeds all the rules of composing and tactility; smell and acoustic quality are just some of the elements of the language that we are required to use in the design process, according to Zumthor. His opinion on architecture through the use of specially selected materials and their correlations is reflected in the final scenario - the sense appears in the moment when the author conducts a specific meaning of the materials in the building, thus, the specific meanings which can be perceived only in this way and only in that building through the use of proportions which regulate the correlations of the materials applied, their brightness and colour, or textures, shades, hardness and weight. If we succeed in these intentions, the architect again may ask what the material can mean in a specific architectural context and in a certain respect, and thus the materials in architecture can be designed to radiate and pulsate, at the same time allowing very sensual impressions of space. ${ }^{16}$

We can consider the perceptive observations of users and viewers relying on the theoretical considerations of Juhani Pallasmaa. His texts are a patent research within architecture with an emphasis on philosophical considerations and psychological research in the field of human perception. Pallasmaa is one of the advocates of phenomenological discourse $e^{17}$ in understanding architecture and in accordance with this, in his texts and monographs through a series of specific sub-topics, he discusses the significance of the unconscious, the dynamics of view, peripheral vision, the obscuring of borders, the sense of continuity, the advantages of uncertainty within experience and creating architectural space and art in general.

As Pallasmaa claims, the importance of the unconscious and peripheral vision is to transform fragmented and sharp retinal images in vague, spacious and embodied experiences that construct plasticity and the experience of a sense of continuity in space. ${ }^{18}$ This is an important statement for considering 
proportions, because thus peripheral vision connects us with space and allows an understanding of the whole, that is, space as the perceived totality composed of separate fragments and their correlations perceived in focus. Also, the human ability to focus on certain elements, colour, shape, and at the end, movement, gives partial pictures which are insufficient although they are specifically allocated, focused on details but as individually memorized they can give a wrong interpretation of the essence, that is, an incorrect understanding of the correlation. On the other hand, peripheral vision complements the interpretation of the whole as an empirical category, which is primarily rational. In this way, the development of creative thinking and understanding of space and the correlations in it as a complex totality is enabled, and not merely a simple sum of empirical experiences rationally interpreted.

\section{THE AESTHETICS OF THE IMMATERIAL | MATERIAL}

Trying to get to the bottom of things, such as the desire to reveal the interior of matter itself, until we reach those particles that, at times, are completely invisible, we can reach something that is in any case unpresentable, immaterial, or according to all the above, the beginning of that which is on the other side within the binary. ${ }^{19}$ Trying to get to the bottom of things, such as the desire to expose the interior of the matter, to reach those particles completely invisible at a certain point, we can reach something that is in any case unpresentable, immaterial, or according to all the above, the beginning of that which is on the other side within the binary. ${ }^{19}$ The ambition of the architect should always be to create something that is more than what can be seen. It is necessary in architecture for form to exceed its basic meaning. The form can be manifested as a character-based structure which refers to a specific domain of reality and through which communication takes place. In addition, the architectural form may encode more information at a given time, which demands of the viewer a multiple cognitive engagement in decoding the message. It is not just a question of one or several individual characters - symbols that appear in architecture through the ages and styles, but the system of symbols that architecture is comprised of. By suggesting content and leaving open potential opportunities, the form is shaped to the extent that it is functionally possible, leading us to the fact that it is crucial what form means, not how it is materialized or how it appears. $^{20}$

This explanation indicates that access to design can reflect a symbol or serve for transmitting ideas - a metaphor, or suggest the meaning that follows a shape - a $\operatorname{sign} .^{21}$ 
The archetypal symbolic forms which the artist during the creative process of creating resorts to intuitively are more or less instinctively interpreted and transformed into new, special metaphorical meanings of contemporary social connotations. In this way, we call the moulded forms, correlations and meanings predictive-metaphorical. This approach to creativity is not considered simple because it searches for the inner reflex of the creator. Complexity is reflected in the interpretation of symbolic form by some kind of intuitive recognition or interpretation of meaning. The degree of the individual which is inevitable affects the fact that the final form is not treated as a symbolic, but as a metaphor. ${ }^{22}$ The metaphor is the one which provides the narration, for, as a rule, symbolic forms lack this feature. In particular, it is necessary to point out that the metaphorical meanings, in this context, are not shaped by rational means, but by individual reflection, and that includes emotional experience and a sense of something familiar and common, substantially close but undefined until the end. ${ }^{23}$

The undefined is a prerequisite for ambiguity and multidimensionality. In order to ensure these conditions, it is necessary for the viewer to have space to interpret the sense of meaning, to complete it in his own way. This is another way to link the spatial structure and the viewer and it is made possible by an implied, reduced meaning, although not clearly defined; and thus is left the possibility of a diverse contextualized interpretation of the viewer himself.

The correlation of the material and immaterial in architectural work is necessary; it justifies the philosophical stipulation that the inner reflexes are criteria which a person is led by in experiencing architectural space as well as space in general. On the other hand, the correlation of the material and the immaterial is a metaphor for correlations between the known and the unknown. The known results from the unknown, while the unknown is treated as a potential of extending the known. Communication that is realized as information sharing, an interactive dialogue between architects and users of architectural work, is one of the forms of crossing from the unknown into the known, as well as overcoming and expanding the domain of the known.

Narration which induces communication through architectural work speaks of the relevant coupling between the architect as a creator and the user as a future interpreter of space. Understanding the essence beyond the material is achieved on an intuitive-metaphorical level through the possibility of interactive communication and a reduced freedom of interpreting architectural structures. As we have already mentioned, the interpretation of architectural structures is 
twofold, and is realized by both the architect and the user, so that the value is reflected in the refracting of the subjective component which is supported by each individual artistic expression and all the complexity of the cultural, social, political aspects of shaping the meaning of an architectural work of art.

TOWARDS PROPORTION -

\section{THE CONCEPT OF PROPORTION FROM AN URBAN PLAN TO URBAN DESIGN AND TO AN ARCHITECTURAL WORK OF ART}

The basic principles of the built environment are the correlations between physical elements and between physical elements and dynamic components. These can be described as spatial packing. ${ }^{24}$ They aggregate on different scales through interactions of dense and separated spaces created by the constitution of space [e.g. the aspect of accessibility and centrality] is determined by its spatial organisation. The term organisation refers to Hillier's terminology of spatial configuration - a set of correlations. ${ }^{25}$ The configuration can be analysed and understood on all scales - from regional planning to urban planning and design, and further to architecture itself. The geometric pattern of spatial configuration of dense and separated spaces is accomplished by a system of piling and accessibility. Every space connects other spaces as well as itself. This scheme repeats itself on all scales to such an extent that we can speak of it as a fractal structure [fragmented, self-similar, multi-scale]. Research has shown that hierarchically structured ordering principles of urban agglomeration are self-organising and exist everywhere where people have to share a limited amount of space. Self-organisation structures the space in traditional European towns as well as in synthetic ones. ${ }^{26}$

The features of a city (fractal structure) demand a structure - an analytical approach to all interacting scales (regional scale, urban scale, and architectural scale). ${ }^{27}$ The idea of hierarchy as a foundation for developing an urban growth model allows an efficient usage of space by using the law of all living systems. The combination of configuration and accessibility (individual transport, public transport) combined with plot sizes, free spaces, building volumes and building heights (population density) puts the built environment in the context of ecological and socio-economic aspects. Regional and urban models which take these factors into consideration represent a holistic strategy for sustainable and sustaining planning. Visionary scenarios demand an interdisciplinary approach from architecture, regional planning and geography. In the course of urban and regional development in Europe over the last decade, sustainable strategies have become the focal point of planning strategies on all scales. ${ }^{28}$ 
Scaling: From regional planning to urban planning and design, and further to architecture itself

The goal is to develop planning scenarios respecting the multiscale logic of the concept. For this aim, predefined standards are applied for developing planning scenarios. The standards refer to the following topics:

- the multi-scale soil occupation index, which corresponds to fractal dimension measures;

- morphological aspects like the articulation of built-up space and open landscape across scales;

- the accessibility of urban amenities (retail centres, services) and green amenities (leisure areas);

- the potential of city-size development (rank-size distribution of cities);

- natural and environmental constraints or recommendations. ${ }^{29}$

Regional scale: From the present situation of a region, a variety of geometric and demographic analyses (agglomeration sizes, agglomeration hierarchies, cluster, population, distances and many others) are carried out to generate the model's scaling factors (reduction factors for a multi-fractal approach) for the best fit (structure-function model).

Urban scale: Instead of using a unique size of elements at each scale the square-like meshes of a grid - we introduce the possibility of combining different sizes of squares, according to multi-fractal logic. This multi-fractal decomposition allows the development of a more architectural approach, taking into account the different sizes of buildings. From a fractal point of view, it is then possible to have a kind of gradient from the centre to the periphery, whereupon larger buildings tend to be localized in the centre. However, fractality allows buildings of different size to be combined in different zones, thus avoiding monotony.

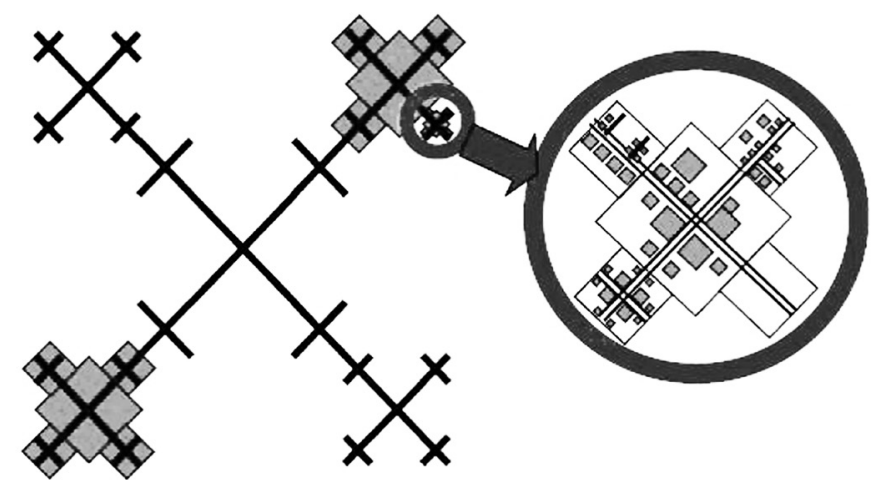

Figure 3. A strategic multi-fractal urban planning scheme (Frankhauser et al. 2005). 
Architectura 7 sca 7e: A multi-fractal approach allows us not only to modify the size of buildings but also to take into account the intensity of land use, i.e. to introduce building height. Hence, we can expect to develop a highly efficient distribution of built-up mass throughout the urban system, which can then link to a well - balanced application of economic theories such as industrial location theories and their impact on the built environment (centrality, accessibility, rent, landscape price, capital, and costs).

The primary reason why systems of proportion have been and continue to be important for architecture is that they enable our buildings to embody a mathematical order that we either distil from or impose upon nature. Besides this, the other reasons commonly put forward - that these systems bring about a pleasing visual harmony, or that through modular coordination they enable building components to fit together neatly and without waste - are relatively trivial. To investigate the parallels between measure in architecture and the mathematics of nature is therefore the basic aim of this study.

The question whether mathematics is inherent in nature and distilled out of it by human reason, or it is a construction of the human mind that we impose upon nature in order to measure it, has been debated by mathematicians and philosophers from as far back as Pythagoras (c. 530 BC). According to the first view, the mathematical order that we discover more or less imperfectly manifested in phenomena constitutes their true or essential nature. The primary purpose of studying mathematics is to penetrate beyond the shifting appearances of things and lay bare this essence. Hermann Weyl, in his book Symmetry, uttered one of the high points of the heyday of proportion in the early 1950s:

There is inherent in nature a hidden harmony that reflects itself in our minds under the image of simple mathematical laws. That then is the reason why events in nature are predictable by a combination of observation and mathematical analysis. ${ }^{30}$

The cognition of urban dynamics and urban design:

the communicative - collaborative dimension of the coastal part of town

The prevailing theory of cognitive urban dynamics is dedicated to the research of the cognitive nature of space and its need is seen as complementing the theory of complexity of cities by considering the cognitive dimensions of the city and the behaviour of the users of urban environments. A correlation between the concepts of structure, change, knowledge and the city are established. Knowledge and awareness of the urban and morphological changes within the 
urban structure, as urban dynamics, is in a permanent correlation with internal personal knowledge of the exterior design of the event, that is, the cognitive urban map. ${ }^{31}$ This in turn establishes a relationship of concepts that offers an explanation of a complex existential value of an area, which is a process that takes place during user interaction and a constructed environment.

Bearing in mind the principle of multi-scale urban and architectural design, from the level of the plan to the level of drawings of architectural conditions, the coastal part of the city can be seen as a means of communication, i.e. as a marketing instrument by which the city communicates with the water and with the users. Thus there is more importance in information that highlights the communicative function of open public spaces and the elements - elements that interpret public space in terms of the users of the space, that is, aspire towards realizing human dimensions of space. Observing space from the viewpoint of a pedestrian suggests dealing with direct experience and the perception of open public spaces, which activates all the human senses.

Putting an emphasis in urban planning and design on human measurements has the task to encourage an increase in pedestrian movement in the form of integrated urban policy whose aim is to develop vibrant, safe, sustainable and healthy cities. This is equally important for the strengthening of the social functions of urban space as a place for meetings and contributes to social sustainability and the creating of an open and democratic society. ${ }^{32}$ During the sixties, several authors tried to find out what makes a city legible. This occurs as a reaction to the destructive impact of modernism on US cities and the extinguishing of urban living within them. For those authors, legibility can be achieved by a reconstruction of the social and symbolic functions of streets and other open public spaces. Accordingly, the loss of human dimensions of space was criticized, which is why these works are based on the observation of the city from the perspective of its inhabitants and everyday users.

\section{Lefebvre: Dimensioning and space partition}

The essence of the formation of the spatial triad of Henri Lefebvre, in The Production of Space, is the highlighting of the complex correlation between the three dimensions of space - mental and real space, where mental implies the philosophical ideas about the same, and the real is actually the physical and social space in which society operates. Actually, this setting can also be interpreted as the author's indication of the complex relationship of theory and practice, or rather, spatial plans and processes of implementing the same with 
reference to the final product in a social context. However, in addition to the aforementioned three dimensions, there is also a fourth dimension, which varies depending on the viewing angle, and refers to time, movement or motion; while in the modern context it can involve a communication space or virtual space.

According to Lefebvre, social space is crucial and it is only in relation to it that mental and physical space can be viewed. Treating social space as key enables the understanding of the correlation between the idea about space and spatial experience. Also, the development of a spatial flow triad that is in constant transformation explains the transition of one spatial type into another, pointing out that the social component of the system as the third space is the basis for the production of urban space. As such, the social space networks through interaction and through the conflict of everything in space created by man or nature. According to Lefebvre, the objective of manufacturing is an integrated inclusive typology of a condition: space, city, society and technology, by which the referred sublimated and transform each other.

Using a poly-inclusive model, spaces in which to acquire and exchange experiences on the hedonic product stand out. ${ }^{34}$

The poly-inclusive model is accepted as an adequate framework for observation. The reason for that is viewed in its communicative character, as each of the separated dimensions - of space - is a framework of communication between the city and its users. In the material area, communication is taking place between the physical environment and the user, which is tantamount to a direct effect of the environment on different senses. Social space includes the interaction between different space users and the ways in which they use the space, but also

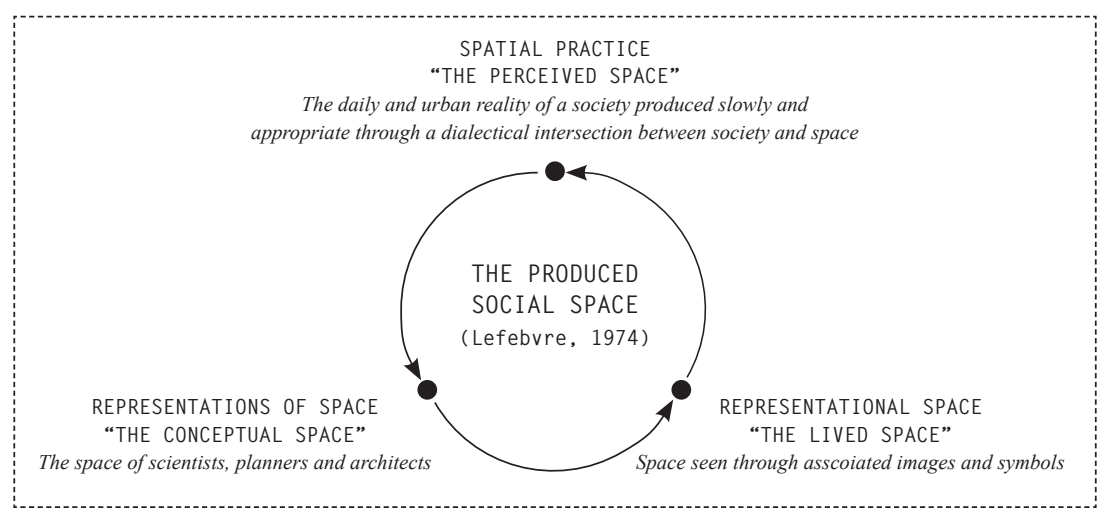

Figure 4. Lefebvre-Diagram of partitioned space ${ }^{33}$ 
a direct exchange of information. Mental space is the one in which cognitive processes take place, creating internal representations that result in the forming of individual or collective images of the city. Virtual or information space is the one in which information is placed, online as well as via mass media. ${ }^{35}$

\section{CONCLUSION}

In an effort to optimize the process of designing architectural facilities, man resorts to tools and methods in order to be able to perceive space and time as categories that are not essentially anthropometric. Accordingly, he resorts to limiting, reducing and fragmenting them. This process has led to the consideration of borders as a necessary means used by man. The border here is a means that will help architects reach dimensions which are close and understandable to man. The constant need to seek answers and ideas that go beyond the obvious has led us to a comparative analysis of the need to establish proportional scales, abstraction and numerical determination of the correlation of elements and the whole - in order to improve knowledge and overcome our own limitations.

Architecture cannot be interpreted as a single term or merely as a material system of mutually established elements, as it is a complete system of the material and immaterial parts of the world. It can also be interpreted as a set or a multitude of proportionally established correlations between analytical fragments in contradiction, arranged in accordance with the opinion of the author and his philosophy of architecture. In this context, architecture is a meaningful unit synthesizing a plurality of elements in a harmonious, proportionally specified correlation. By separating elements via analysis, we are able to observe some aspect of the whole, which is always wider than the simple sum of its own elements. The interpretation of the architectural structure is two-fold, achieved by both the architect and the user, so that the value is reflected in the diffraction of subjective components carried by each individual artistic expression and all the complexity of cultural, social, political aspects of shaping the meaning of an architectural work of art.

An architect as the author of a project is not limited in the process of creating through personal affinities and aesthetic qualities that impress him personally, but rather, he has the opportunity to express his creative thinking through the process of creating his own architectural work of art. We believe that from the development of creative potential we can realize the importance of the matter in the fact that spontaneity plays its role in the creative process, in this way 
preventing a repetition and servicing conventions. On the other hand, design techniques need to be enhanced by visual arts in order to produce a measure of elusiveness and extraordinariness in architecture.

An architectural work represents a spatial span formed by a studied attitude and an arrangement with the masses.

Architecture is the mastering, that is, the spanning of space rather than the building of elements and objects in space. ${ }^{36}$

However, architecture is not just a simple inclusion of space, setting it up and designing it, but the comprehension and understanding of the same. It is possible that an architect can find the stronghold of his ideas and the personal conventions guiding him by interpreting philosophy through his own affinities, drawing in metaphysics into spatial spans that at first glance are quite materially ordinary - giving them the essence that goes beyond what can easily be sensually perceived.

From this paper it is possible to continue research, going into a detailed analysis of various design techniques from different angles, theoretically grounded in philosophy, continuing to analyze the ways to use design techniques of other visual arts through different historical and theoretical manifestations of design. By considering the manifestations of design in the architecture of specific eras/styles, it is possible to notice certain repetitions or matrices, models and methods. An architect does not have to be a good painter or a skilled sculptor, but he needs to know the possibilities offered to him by having knowledge of urban planning, design techniques and fine arts, which he can in many ways incorporate into his creative work and elevate buildings to the rank of sublime works of the modern architecture discourse - the sublime (concinnitas) and beauty (venustas). 
NOTES

1

2

3

5

6

Volume: capacity, comprehensiveness.

Stephan Pheasant, Bodyspace - Antropometry, Ergonomics and the Design of Work, (London: Taylor\&Francis Ltd, 2003), 7.

Art History: Thinking and Talking about Art, 2017. Last modified January 1, 2017. http:// brewminate.com/art-history-thinking-and-talking-about-art/.

Vitruvius, The Ten Books On Architecture (Cambridge: Harvard University Press, 1914), III, Ch. 1. Gestalt [eng. gestalt] - An organized whole is larger/more complex than the sum of its parts.

Golden ratio 1:f = f:1.618; Fibonacci numbers: 1,1,2,3,5,8,13,21,34...; Vitruvian Man (L'Uomo Vitruviano), depicting a man in two superimposed positions with his arms and legs apart and inscribed in a circle and square, a drawing by Leonardo da Vinci accompanied by notes based on the work of the architect Vitruvius, created around 1487.

Pavle Stamenović, Generički okvir arhitektonskog projekta: instrumentalizacija tipološke ambivalentnosti (PhD diss., University of Belgrade - Faculty of Architecture, 2015), 95.

Jean - Louis Cohen, Le Corbusier's Modulor and the Debate on Proportion in France, Architectural Histories, 2, no.1 (2014), 1-14.

Ergonomics - is a discipline whose task is based on the results of empirical research of anthropometric, dynamic, sensory and psychological characteristics of the human body and behavior, providing defined parameters and recommendations of the adjustment of items, the environment and processes to man, who comes into contact with them. Saopštenje Br. 14 (Beograd: Univerzitet u Beogradu - Arhitektonski fakultet, 1971).

Le Corbusier, Ka novoj arhitekturi (Beograd: Građevinska knjiga, 2006), 51.

"Saopštenja" [eng. Notices] - "Saopštenje 1970-71" consists of 14 issues of bulletins which were published as of 20 November 1970 until 8 June 1971, with an additional special issue published on 21 April 1971 and bound at the end of the collected bulletins. It is interesting to note that in the course of publishing "Saopštenja" the pagination was done which consequently represents the continuation of page marking from one publication to the next, so that the entire number of pages of "Saopštenje" amounts to 170 with 12 pages of appendices. Milorad Mladenović, COMMENTS ON ("SAOPŠTENJA") OF THE NEW SCHOOL (OF ARCHITECTURE), SAJ - Serbian Architectural Journal, Vol. 3, 2011, No.1, 37-78.

Vladimir Mako, Estetika - arhitektura, Knjiga 2 (Beograd: Orion Art, 2005), 29-34.

Vladimir Mako, Estetika - arhitektura: Sedam tematskih rasprava (Beograd: Orion Art, 2005), 109-111.

Peter Zumthor, Thinking Architecture (Basel: Birkhäuser, 1998), 10-11.

Ibid.

Ibid.

Phenomenology - The philosophical movement that explores the structures of experience and consciousness. The phenomenon is what appears in the consciousness, something shown to the senses as such, or what is revealed. In the philosophical sense, the phenomenon is what is shown and reveals itself to itself. Miško Šuvaković, Pojmovnik suvremene umjetnosti (Zagreb: Horetzky, 2005), 203.

Phenomenology [gr. phainomenon - phenomenon, logia - learning] phil. learning about phenomena [as opposed to learning about the "thing in itself"]; the science of natural phenomena as well as expressions, powers, etc., of the spirit with respect to development and mutual correlation. Milan, Vujaklija, Leksikon stranih reči i izraza (Beograd: Prosveta 1980), 960.

Juhani Pallasmaa, LOSS OF SPECIFICTY AND SENSE OF CONTINUITY from Encounters 2 - Architectural Essays, ed. Peter MacKeith (Helsinki: Rakennustieto Publishing, 2012), 233-234. Jean Baudrillard; Jean Nouvel, The singular objects of architecture. Architecture - Philosophy (Minneapolis: The University of Minnesota Press, 2002), 31. 
Ibid.

Georg Franck, „Werben und Überwachen: Zur Transformation des städtischen Raums“. In: Bild - Raum - Kontrolle. Videoüberwachung als Zeichen gesellschaftlichen Wandels, ed. von Leon Hempel und Jörg Metelmann (Frankfurt/Main: Suhrkamp, 2005), 141-155.

Bill Hiller, Space is the machine: A configurational theory of architecture, (US-SC-North Charleston: CreateSpace Independent Publishing Platform, 2016).

Michael Batty, Paul A. Longley, Fractal cities: A geometry of form and function, (London: Academic Press, 1994).

Pierre Frankhauser, "Fractal geometry for measuring and modelling urban patterns". In: The dynamics of complex urban systems - An Interdisciplinary Approach, eds. Sergio Albeverio et al. (Heidelberg: Physica - Verlag HD, 2008), 213-243.

Claudia Czerkauer-Yamu, Pierre Frankhauser, “A multi-Scale (Multi-Fractal) approach for a systemic planning strategy from a regional to an architectural scale". In REAL CORP 2010 Proceedings (Competence Center of Urban and Regional Planning, Association for Promotion and Research of Urban Planning and Regional Development in the Information Society), Vienna, 2010, 17-26. Ibid.

Hermann Weyl, quoted in Morris Kline, Mathematics: The Loss of Certainty, Vol. 686 (New York: Oxford University Press, 1980), 347.

Reginald G. Golledge, Wayfinding behavior: Cognitive mapping and other spatial processes, (Baltimore and London: The Johns Hopkins University Press, 1999), 5-45.

Milena Vukmirović, Značaj i uloga mreže pešačkih prostora u generisanju kompetitivnog identiteta grada, (PhD diss., Univerzitet u Beogradu - Arhitektonski fakultet, 2015), 45.

See: Henri, Lefebvre, The Production of Space (Malden: Blackwell publishing, 1991), 31-33.

Robert Govers, Frank Go, Place Branding. Global, Virtual and Physical Identities, Constructed, Imagined and Experienced (Hampshire: Palgrave MacMillan, 2009), 7.

Milena Vukmirović, Značaj i uloga mreže pešačkih prostora u generisanju kompetitivnog identiteta grada, (PhD diss., Univerzitet u Beogradu - Arhitektonski fakultet, 2015), 55.

Bernard Tschumi, Architecture and Disjunction (London: The MIT Press, 1996). 
Batty, Michael; Longley, Paul A. Fractal cities: A geometry of form and function, (London: Academic Press, 1994).

Baudrillard, Jean; Nouvel Jean. The singular objects of architecture. Architecture - Philosophy (Minneapolis: The University of Minnesota Press, 2002).

Cohen, Jean - Louis. Le Corbusier's Modulor and the Debate on Proportion in France, Architectural Histories, 2, no.1 (2014).

Czerkauer-Yamu, Claudia; Frankhauser, Pierre. "A multi-Scale (Multi-Fractal) approach for a systemic planning strategy from a regional to an architectural scale". In REAL CORP 2010 Proceedings (Competence Center of Urban and Regional Planning, Association for Promotion and Research of Urban Planning and Regional Development in the Information Society), Vienna, 2010.

Eko, Umberto. Kultura, informacija, komunikacija (Beograd: Nolit, 1973).

Franck, Georg. „Werben und Überwachen: Zur Transformation des städtischen Raums“. In: Bild - Raum - Kontrolle. Videoüberwachung als Zeichen gesellschaftlichen Wandels, ed. von Leon Hempel und Jörg Metelmann (Frankfurt/Main: Suhrkamp, 2005).

Frankhauser, Pierre. "Fractal geometry for measuring and modelling urban patterns". In: The dynamics of complex urban systems - An Interdisciplinary Approach, eds. Sergio Albeverio et al. (Heidelberg: Physica - Verlag HD, 2008).

Hiller, Bill. Space is the machine: A configurational theory of architecture, ( US-SC-North Charleston: CreateSpace Independent Publishing Platform, 2016).

Golledge, Reginald G. Wayfinding behavior: Cognitive mapping and other spatial processes, (Baltimore and London: The Johns Hopkins University Press, 1999).

Govers, Robert, Go, Frank Place Branding: Glocal, Virtual and Physical Identities, Constructed, Imagined and Experienced, (Hampshire: Palgrave MacMillan, 2009).

Kordić, Milena. Međuprostor, (Beograd: Zadužbina Andrejević, 2012).

Le Corbusier, The Modulor: A Harmonious Measure to the Human Scale Universally Applicable to Architecture and Mechanics (London: Faber \& Faber, 1956).

Le Corbusier, Ka novoj arhitekturi (Beograd: Građevinska knjiga, 2006).

Lefebvre, Henri. The Production of Space (Malden: Blackwell publishing, 1991).

Mako, Vladimir. Estetika-arhitektura: Sedam tematskih rasprava, (Beograd: Orion Art, 2005).

Mako, Vladimir. Estetika-arhitektura, Knjiga 2, (Beograd: Orion Art, 2005).

Mladenović, Milorad. "Comments on ("Saopštenja”) of the New School (of Architecture)," SAJSerbian Architectural Journal, Vol. 3, 2011, No. 1, 37-78.

Pallasmaa, Juhani. "Loss of Specificty and Sense of Continuity". In: Encounters 2 -Architectural Essays, ed. Peter MacKeith (Helsinki: Rakennustieto Publishing, 2012).

Pheasant, Stephan. Bodyspace - Antropometry, Ergonomics and the Design of Work, (London: Taylor\&Francis Ltd, 2003).

Saopštenje Br. 14 (Beograd: Univerzitet u Beogradu - Arhitektonski fakultet, 1971).

Stamenović, Pavle. Generički okvir arhitektonskog projekta: instrumentalizacija tipološke ambivalentnosti (PhD diss., University of Belgrade - Faculty of Architecture, 2015).

Šuvaković, Miško. Pojmovnik suvremene umjetnosti (Zagreb: Horetzky, 2005).

Vitruvius, The Ten Books On Architecture (Cambridge: Harvard University Press, 1914).

Vujaklija, Milan. Leksikon stranih reči i izraza (Beograd: Prosveta 1980).

Vukmirović, Milena. Značaj i uloga mreže pešačkih prostora u generisanju kompetitivnog identiteta grada, (PhD diss., Univerzitet u Beogradu - Arhitektonski fakultet, 2015).

Weyl, Hermann. Quoted in Kline Morris, Mathematics: The Loss of Certainty, Vol. 686 (New York: Oxford University Press, 1980).

Zumthor, Peter. Thinking Architecture (Basel: Birkhäuser, 1998). 


\section{RAZMERA NA PAPIRU IZMEDJU TEHNIKE I IMAGINACIJE. PRIMER KONSTANTOVE CRTAČKE PRETPOSTAVKE \\ Anđelka Bnin-Bninski, Maja Dragišić}

Postupak razmeravanja je jedna od osnovnih radnji u arhitektonskom crtanju. Uz papir kao kao osnovni materijal za crtanje, razmera predstavlja arhitektonsku konvencija odmah po samom crtanju u arhitekturi Renesanse. U ovom radu ispituje se procedura razmeravanja iz pozicije crteža u idejno-stvaralačkom arhitektonskom procesu. Aktuelna teorijska istraživanja o arhitektonskom crtežu ističu promenu paradigme koja se dogodila usled iznenadnog prelaska sa ručnog na kompjuterski crtež. Ova promena je posledično uticala na materijalni značaj crtanja/crteža, odnosa prema razmeri i geometriji. Argumentujući razmeru kao dvoznačnu radnju, tehničku i kreativnu, Konstantovi crteži Novog Vavilona uzeti su kao primer problematizacije relacionog lanca arhitekta - projekat - objekat.

KLJUČNE REČI: ARHITEKTONSKI CRTEŽ, RAZMERA, PAPIR, CRTEŽ STANOVANJA, KONSTANTOV NOVI VAVILON

\section{IZVAN PROPORCIJA \\ Reinterpretacija proporcija - između konceptualnog $i$ \\ perceptivnog mišijenja arhitekture \\ (komunikativna dimenzija grada)}

\section{Miloš Mihajlović, Aleksandra Subotić, Vladimir Parežanin}

Rad posmatra proporcuju kao alat kojim se urbanista i arhitekta koriste da bi se postigao određeni kvalitet prostora. Kako se kroz proporciju posmatraju odnosi celine i njenih delova, tako rad sagledava aspekte prostora od prostornog plana grada do arhitektonskog detalja. Takođe, i pored toga što je proporcija odnos dimenzija fizičkih elemenata u prostoru, rad razmatra proporciju i kroz odnos materijalnih i nematerijalnih aspekata prostora. Na taj način, težište rada je pomereno na nivo komunikacije između arhitektonsko-urbanističkog prostora i njegovih korisnika, odnosno na orkestraciju kroz percepciju i doživljaj prostora, a ne na prevaziđenu, proporcijsku analizu arhitektonske forme.

KLJUČNE REČI: ARHITEKTONSKO PROJEKTOVANJE, ISTRAŽIVANJE KROZ DIZAJN, ODNOS, PROPORCIJE, ESTETIKA, MODULOR, REZILIJENTNOST

\section{MODELI TRANSFORMACIJE NEISKORIŠČENIH PROSTORNIH RESURSA Istraživačka studija KC Magacin u Beogradu \\ Ksenija Pantović, Iva Čukić}

Ovaj rad istražuje različite modele transformacije neiskorišćenih prostornih resursa, u cilju prepoznavanja aspekata koji vode održivom aktiviranju prostora. Značaj istraživanja ogleda se i u naučnoj interpretaciji i pojašnjenju fenomena transformacije $u$ aktiviranju neiskorišćenih prostornih resursa, i to u kontekstu post-socijalističke Srbije sa posebnim fokusom na glavni grad. Istovremeno, ovaj rad predstavlja i doprinos metodologiji arhitektonskog projektovanja, kroz ukazivanje na značaj primene modela transformacije u projektantskom procesu. U tom kontekstu, teorijski okvir istraživanja se odnosi na različite aspekte urbane održivosti u kontekstu aktiviranja neiskorišćenih prostornih resursa, kao i na dublje razjašnjavanje uloge principa transformacije u arhitektonskom diskursu. Empirijski deo istraživanja se odnosi na analizu studije slučaja konkretnog prostornog okvira Kulturnog centra Magacin u Beogradu i to metodom sprovođenja studentske radionice. Studenti istražuju različite mogućnosti transformacije i aktivacije prostora, kroz niz predloženih intervencija. Završni deo rada obuhvata sintezu i interpretaciju rezultata u odnosu na kontekst istraživanja i postavljene problemske postavke, ali što je značajnije, daje stepen uslovljenosti 